\title{
PRIMARY MURINE CORONAVIRUS INFECTION IN MICE
}

\section{A Flow Cytometric Analysis}

\author{
S. Kyuwa, ${ }^{1}$ K. Machii, ${ }^{2}$ A. Okumura, ${ }^{1}$ and $\mathrm{Y}$. Toyoda ${ }^{1}$ \\ ${ }^{1}$ Department of Animal Pathology \\ Institute of Medical Science \\ University of Tokyo \\ Tokyo, Japan \\ ${ }^{2}$ Department of Veterinary Public Health \\ Institute of Public Health \\ Tokyo, Japan
}

T cell- mediated immune responses play a pivotal role in both viral clearance and immunopathology in mice infected with murine coronavirus, strain JHM (JHMV) ${ }^{1,2}$. In the present study, we attempted to characterize T cells induced during primary JHMV infection by flow cytometric analysis.

Female, 6 to 8 week old C57BL/6 (B6) mice were infected intraperitonealy with $10^{6}$ PFU of JHMV. Although JHMV replicated for the first 3 days but was eliminated from spleens of B6 mice at 7 days postinfection (pi). Flow cytometric analysis was caried out to characterize spleen cells from JHMV-infected B6 mice. ${ }^{3}$ Most drastic changes were noted as an increased number of $\mathrm{CD}^{+} \mathrm{T}$ cells and their decreased CD8 intensity at 7 days pi. Time course study showed that intensity of $\alpha \beta$ T cell receptors declined with the CD8 intensity, while intensity of the lymphocyte function antigen-1 (LFA-1) and CD43 on CD8 ${ }^{+} \mathrm{T}$ cells increased. Two-color analysis demonstrated that CD ${ }^{\text {dull }} \mathrm{LFA}-1^{\text {bright }} \mathrm{T}$ cells were induced transiently in both C57BL/6 and BALB/c mice following JHMV infection (Figure 1). At 7 days pi a half of $C D 8^{+} T$ cells were partitioned into $C D 8^{\text {dull }}$ LFA- $1^{\text {bright }} T$ cells. Forward and side scatter profiles of $C D 8^{\text {dull }} L F A-1^{\text {bright }} \mathrm{T}$ cells indicated that the population appeared to be activated T cells. Although $\mathrm{CD} 45 \mathrm{RB}^{\text {dull }} \mathrm{CD} 8^{+}$and $\mathrm{CD} 44^{\text {bright }} \mathrm{CD} 8^{+} \mathrm{T}$ cells were observed in $\mathrm{JHMV}$-infected mice, expansion of $\mathrm{CD} 25^{+} \mathrm{CD} 8^{+}$and $\mathrm{CD} 11 \mathrm{~b}^{+} \mathrm{CD} 8^{+} \mathrm{T}$ cells, which were reported as markers of cytotoxic $\mathrm{T}$ lymphocytes in choriomeningitis virus infection in mice ${ }^{4,5}$, was not observed. Since the kinetics of the expansion of CD8 ${ }^{\text {dull }}$ LFA- $1^{\text {bright }} \mathrm{T}$ cells was correlated with the viral elimination in vivo, we measured fresh cytotoxic activities of spleen cells from JHMV-infected B6 mice against syngeneic JHMV-infected macrophagelike cell line (IC-21 cells). The $\mathrm{Ig}^{-}$splenocytes from mice 7 days pi but neither those from uninfected or 14 days pi showed a weak, but significant cytotoxic activity against JHMVinfected H-2-matched cells in vitro. Therefore, these results suggest that the T cell population 

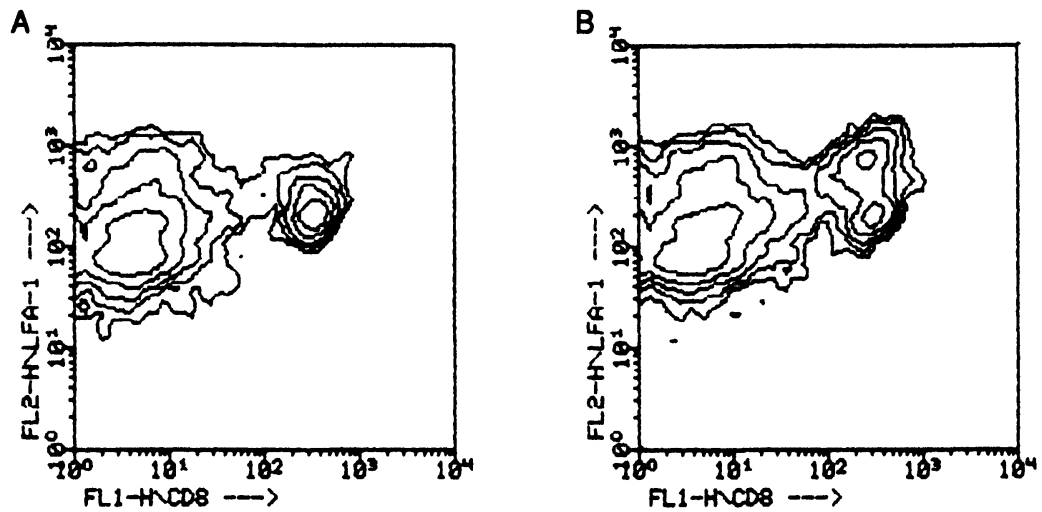

Figure 1. Two- color analysis of spleen cells from uninfected B6 mouse (A) and that at 7 days pi (B). Spleen cells were stained with anti-CD8 (FL1) and anti-LFA-1 (FL2) (antibodies, and analyzed by a FACScan ${ }^{\mathrm{TM}}$ flow cytometer.

may mediate the cytotoxicity against virus- infected cells in vivo, and thus the flow cytometric analysis is applicable to monitor coronavirus- induced primary cytotoxic $\mathrm{T}$ lymphocytes population in vivo.

\section{REFERENCES}

1. Kyuwa, S., Stohlman, S.A. Pathogenesis of a neurotropic murine oronavirus, strain JHM, in the central nervous system of mice. Semin Virol 1990;1:273-280.

2. Fleming, J.O., Wang, F.I., Trousdale, M.D., Hinton, D.R., Stohlman, S.A. Interaction of immune and central nervous system; contribution of anti-viral Thy $-1^{+}$cells to demyelination induced by coronavirus JHM. Reg Immunol 1993;5:37- 43.

3. Kyuwa, S., Machii, K., Okumura, A., Toyoda, Y. Induction of LFA- $1^{\text {high }} \mathrm{CD} 8^{+} \mathrm{T}$ cells associated with antiviral cytotoxicity during primary murine coronavirus infection in mice. Submitted.

4. Saron, M.F., Colle, J.H., Dautry- Varsat, A., Truffa- Bachi, P. Activated T lymphocytes from mice infected by lymphocytic choriomeningitis virus display high affinity IL-2 receptors but do not proliferate in response to IL-2. J Immunol 1991;147:4333-4337.

5. McFarland, H.I., Nahill, S.R., Maciaszek, J.W., Welsh, R.M. CD11b (Mac-1): a marker for CD8 ${ }^{+}$cytotoxic $T$ cell activation and memory in virus infection. J Immunol 1992; 149:1326-1333. 